\title{
Cardiac $\mathbf{G}_{\mathrm{s} \alpha}$ overexpression enhances L-type calcium channels through an adenylyl cyclase independent pathway
}

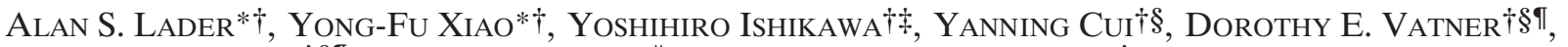 \\ Stephen F. Vatner $\uparrow \S \pi$, Charles J. Homcyll, and Horacio F. Cantiello* $* * * *$ \\ ${ }^{*}$ Renal Unit, Massachusetts General Hospital East, Charlestown, MA 02129; $\$$ Brigham and Women’s Hospital, Boston, MA 02115; §New England Regional \\ Primate Research Center, Southborough, MA 01772; "COR Therapeutics, South San Francisco, CA 94080; and †Department of Medicine, Harvard Medical \\ School, Boston, MA 02115
}

Edited by Lutz Birnbaumer, University of California, Los Angeles, CA, and approved May 22, 1998 (received for review June 30, 1997)

\begin{abstract}
The $\alpha$ subunit of the stimulatory heterotrimeric $G$ protein $\left(G_{s \alpha}\right)$ is critical for the $\beta$-adrenergic receptor activation of the cAMP messenger system. The role of $G_{s \alpha}$ in regulating cardiac $\mathrm{Ca}^{2+}$ channel activity, however, remains controversial. Cultured neonatal cardiac myocytes from transgenic mice overexpressing cardiac $G_{s \alpha}$ were used to assess the role of $G_{s \alpha}$ on the whole-cell $\mathrm{Ca}^{2+}$ currents $\left(I_{\mathrm{Ca}}\right)$. Cardiac myocytes from transgenic mice had a $490 \%$ higher peak $I_{C a}$ compared with those of either wild-type controls or $\mathbf{G}_{\mathrm{s} \alpha}$-nonexpressing littermates. The effect of $\mathbf{G}_{\mathrm{s} \alpha}$ overexpression was mimicked by intracellular dialysis of wild-type cardiac myocytes with GTP $\gamma \mathrm{S}$-activated $\mathrm{G}_{\mathrm{s} \alpha}$. This effect was not mediated by protein kinase $\mathrm{A}$ activation as intracellular perfusion with a protein kinase $A$ inhibitor rendered the same degree of activation in either transgenic or wild-type myocytes also dialyzed with activated $G_{\mathrm{s} \alpha}$. The data indicate that $\mathbf{G}_{\mathrm{s} \alpha}$ overexpression is associated with a constitutive enhancement of $I_{C a}$ which is independent of the cAMP pathway and activation of endogenous adenylyl cyclase.
\end{abstract}

Cardiac L-type $\mathrm{Ca}^{2+}$ channel activity, an important contributor to cardiac electrical activity and contractile function, is regulated by sympathetic nerve stimulation. The $\beta$-adrenergic receptor $(\beta-\mathrm{AR})$ control of L-type $\mathrm{Ca}^{2+}$ channels is associated with the signal transduction pathway implicating stimulation of cAMP-dependent protein kinase A (PKA) through activation of the heterotrimeric stimulatory GTP-binding protein $\left(\mathrm{G}_{\mathrm{s}}\right)$, which, in turn, induces cAMP production by adenylyl cyclase. The $\beta$-AR regulation of L-type $\mathrm{Ca}^{2+}$ channel activity has been previously associated with PKA targeting of the channels (1). However, $\beta$-AR activation of $\mathrm{G}_{\mathrm{s} \alpha}$ may, in itself, have a more direct effect on the $\mathrm{Ca}^{2+}$ channels. Although previous studies have provided evidence for a more direct role of $\mathrm{G}_{\mathrm{s} \alpha}$ in the regulation of L-type $\mathrm{Ca}^{2+}$ channel activity (2), others have contested these findings, at least in the context that $\beta$-AR stimulation required an active cAMP pathway to enhance L-type $\mathrm{Ca}^{2+}$ channel activity (3). Thus, various, although not mutually exclusive, regulatory mechanisms may be at work on the basal and adrenergically stimulated regulation of L-type $\mathrm{Ca}^{2+}$ channels.

A transgenic mouse has been recently developed in which $\mathrm{G}_{\mathrm{s} \alpha}$ is selectively overexpressed in the heart (4). A threefold to fourfold increase in protein content was observed in mice expressing the $\mathrm{G}_{\mathrm{s} \alpha}$ transgene along with an approximate doubling of $\mathrm{G}_{\mathrm{s} \alpha}$ activity (ref. 4 and unpublished observations). Thus, the goal of the present study was to investigate the consequences of cardiac $\mathrm{G}_{\mathrm{s} \alpha}$ overexpression on basal cardiac L-type $\mathrm{Ca}^{2+}$ channel activity in neonatal cardiac myocytes

The publication costs of this article were defrayed in part by page charge payment. This article must therefore be hereby marked "advertisement" in accordance with 18 U.S.C. $\$ 1734$ solely to indicate this fact.

(C) 1998 by The National Academy of Sciences 0027-8424/98/959669-6 $\$ 2.00 / 0$ PNAS is available online at www.pnas.org. from $\mathrm{G}_{\mathrm{s} \alpha}$-overexpressing transgenic mice, as well as from control littermates, and wild-type mice. The data indicate that $\mathrm{G}_{\mathrm{s} \alpha}$ overexpression alone is sufficient to mediate a signal transduction mechanism which constitutively enhances L-type $\mathrm{Ca}^{2+}$ currents independent of the cAMP pathway.

\section{MATERIALS AND METHODS}

Primary Cultures of Neonatal Mouse Cardiac Myocytes. Primary cultures of neonatal mouse cardiac myocytes were obtained with procedural modifications to a commercial isolation kit originally developed for neonatal rat ventricular myocytes (Worthington). Pregnant mice used as wild-type controls (C57BL/6J, +/+, P100) were a kind gift from Richard L. Sidman and Aizhong Li (New England Regional Primate Research Center, Harvard Medical School). Briefly, beating hearts were harvested from less than 24-hr-old neonatal mice and immediately placed in a $\mathrm{Ca}^{2+}$ and $\mathrm{Mg}^{2+}$-free Hanks' balanced salt solution (Worthington). The connective tissue was dissected out and hearts were minced and subjected to trypsin $(100 \mu \mathrm{g} / \mathrm{ml}$ in Hanks' balanced salt solution $)$ digestion for $16-18 \mathrm{hr}$ at $4^{\circ} \mathrm{C}$. Trypsin digestion was stopped by addition of trypsin inhibitor (Worthington). Further collagenase digestion (Type II collagenase, 150 units/ml; Worthington) was conducted at $37^{\circ} \mathrm{C}$ on a shaking bath for $45 \mathrm{~min}$. Cell clumps were flushed through a pipette, centrifuged, and washed with fresh Leibovitz L-15 medium. Cell pellets were resuspended in Ham's F-10 medium with L-glutamine (BioWhittaker) also containing $5 \%$ bovine serum and $10 \%$ horse serum (BioWhittaker). Cells were seeded onto glass coverslips and allowed to grow at $37^{\circ} \mathrm{C}$ in an incubator gassed with $5 \% \mathrm{CO}_{2}$. Healthy (beating) cells were observed after $24 \mathrm{hr}$ in culture and were usually healthy for up to $1 \mathrm{wk}$ with no apparent electrical differences at the various times in culture. All experiments were performed on cells after at least $24 \mathrm{hr}$ but less than 5 days in culture.

$\mathbf{G}_{\mathbf{s} \boldsymbol{\alpha}}$ Transgenic Mice. The $\mathrm{G}_{\mathrm{s} \alpha}$ transgenic mouse model uses a rat myosin heavy chain promoter to initiate the selective expression of the cardiac $\mathrm{G}_{\mathrm{s} \alpha}$ transgene, consisting of exons 1-12 of canine $\mathrm{G}_{\mathrm{s} \alpha} \mathrm{cDNA}$, followed by a portion of the human $\mathrm{G}_{\mathrm{s} \alpha}$ gene for intron 12 , exon 13 , and the polyadenylation signal (4). Heterozygous $\mathrm{G}_{\mathrm{s} \alpha}$ transgenic mice were mated and litters were taken at approximately $24 \mathrm{hr}$ after delivery. Each individual heart was processed independently as described above. Neonatal heart cells from each littermate were cultured sep-

This paper was submitted directly (Track II) to the Proceedings office. Abbreviations: $\beta$-AR, $\beta$-adrenergic receptor; PKA, protein kinase A; $\mathrm{G}_{\mathrm{s} \alpha}, \alpha$ subunit of the stimulatory heterotrimeric $\mathrm{G}$ protein; $\mathrm{G}_{\mathrm{s}}$, stimulatory GTP-binding protein; PKI, protein kinase inhibitor.

"Present address: Cardiovascular and Pulmonary Research Institute, Allegheny University of the Health Sciences, Pittsburgh, PA 15212.

**To whom reprint requests should be addressed at: Renal Unit, 8th Floor, Massachusetts General Hospital East, 149 13th St., Charlestown, MA 02129. 
arately onto glass coverslips placed in 24-well tissue culture plates (Falcon 3047; Becton Dickinson). Experiments were performed blindly on each of the cultures and expression of the $\mathrm{G}_{\mathrm{s} \alpha}$ transgene was later confirmed by Southern blotting.

Screening for the $\mathbf{G}_{\mathbf{s} \boldsymbol{\alpha}}$ Transgene. The presence of the $\mathrm{G}_{\mathrm{s} \alpha}$ transgene was determined by Southern blotting as described previously $(4,5)$ using $10 \mu \mathrm{g}$ of genomic DNA isolated from the neonatal mouse tails, which were kept in liquid nitrogen until the time of the experiment.

Whole-Cell Currents. Patch pipettes were made with WPI150 glass capillaries (World Precision Instruments, Sarasota, FL), fire polished, and filled with the following solution: 125 $\mathrm{mM} \mathrm{CsCl}, 20 \mathrm{mM}$ tetraethylammonium-Cl, $10 \mathrm{mM}$ Hepes, 5 $\mathrm{mM} \mathrm{MgATP}$, and $5 \mathrm{mM}$ EGTA at $\mathrm{pH} 7.3$ with $\mathrm{CsOH}$. The bathing solution consisted of: $140 \mathrm{mM} \mathrm{NaCl}, 5 \mathrm{mM} \mathrm{CsCl}, 2 \mathrm{mM}$ $\mathrm{CaCl}_{2}, 1 \mathrm{mM} \mathrm{MgCl} 2,10 \mathrm{mM}$ Hepes at $\mathrm{pH} 7.4$ with $\mathrm{NaOH}$. CsCl was substituted for $\mathrm{KCl}$ to eliminate $\mathrm{K}^{+}$channel activity. Actual currents and step potentials were obtained and driven with a Dagan 3900 (Dagan Corp., Minneapolis, MN). Signals were filtered at $2 \mathrm{KHz}$ with an eight-pole Bessel filter (Frequency Devices, Haverhill, MA) and data were stored in a hard disk of a personal computer to be analyzed with PClamp 6.0.3 (Axon Instruments, Burlingame, CA). $\mathrm{I}_{\mathrm{Ca}}$ current-voltage relationships were obtained by applying $200 \mathrm{~ms}$ of $10-\mathrm{mV}$ voltage steps between $-60 \mathrm{mV}$ and $70 \mathrm{mV}$, starting from a holding potential of $-50 \mathrm{mV}$. The $\mathrm{I}_{\mathrm{Ca}}$ was determined by subtracting the peak inward (negative) currents from the currents measured at $190 \mathrm{~ms}$. This protocol has been reported to effectively eliminate contamination of $\mathrm{I}_{\mathrm{Ca}}$ by voltageactivated $\mathrm{Na}^{+}$channels (6).

Sodium currents $\left(\mathrm{I}_{\mathrm{Na}}\right)$ were obtained by applying $200 \mathrm{~ms}$ of $10-\mathrm{mV}$ voltage steps between $-80 \mathrm{mV}$ and $50 \mathrm{mV}$ from a holding potential of $-90 \mathrm{mV}$. The pipette and bath solutions were as specified for the $\mathrm{I}_{\mathrm{Ca}}$ measurements. The $\mathrm{I}_{\mathrm{Na}}$ was determined by subtracting the peak inward (negative) currents from the currents measured at $190 \mathrm{~ms}$.

cAMP-stimulated $\mathrm{Cl}^{-}$currents were measured by applying 20 - $\mathrm{mV}$ voltage steps for $500 \mathrm{~ms}$ between $\pm 100 \mathrm{mV}$ from a holding potential of $0 \mathrm{mV}$ under the same ionic conditions used for the $\mathrm{I}_{\mathrm{Ca}}$ and $\mathrm{I}_{\mathrm{Na}}$ measurements. The linear and time-independent whole-cell $\mathrm{Cl}^{-}$conductance was calculated from currents measured at $490 \mathrm{~ms}$ after applying the voltage steps (7).

Dihydropyridine Binding with $\left[{ }^{3} \mathrm{H}\right]$ PN200-110. $\mathrm{G}_{\mathrm{s} \alpha}$ overexpressed transgenic and wild-type control mouse hearts were homogenized in ice-cold assay buffer consisting of: $145 \mathrm{mM}$ $\mathrm{NaCl}, 5 \mathrm{mM} \mathrm{KCl}, 1.25 \mathrm{mM} \mathrm{MgCl}_{2}, 1.25 \mathrm{mM} \mathrm{CaCl}_{2}$, and $20 \mathrm{mM}$ Tris $\cdot \mathrm{HCl}$ (pH 6.7). The hearts were homogenized with a Polytron using a setting of 6.5 for $5 \mathrm{~s}$ ( homogenate was centrifuged for $20 \mathrm{~min}$ at $14,000 \times g$. The pellet was resuspended using a Polytron for $5 \mathrm{~s}$ at half-speed. The homogenate was centrifuged as above. This procedure was repeated twice. The pellet was then resuspended in assay buffer containing $0.05 \%$ BSA and filtered through a nylon mesh.

Eight concentrations of $\left[{ }^{3} \mathrm{H}\right] \mathrm{PN} 200-110(0.05-2 \mathrm{nM}, 25 \mu \mathrm{l}$; New England Nuclear) were used with $40 \mu \mathrm{g}$ of membrane protein $(100 \mu \mathrm{l})$ and $10 \mu \mathrm{M}$ nifedipine or assay buffer $(25 \mu \mathrm{l})$. The assay was performed in triplicate, incubated for $1 \mathrm{hr}$ at $37^{\circ} \mathrm{C}$, and filtered on Whatman $\mathrm{GF} / \mathrm{F}$ filters with a Brandel cell harvester (Bethesda, MD). The assay was performed in a dark room with a red lamp because of the light sensitivity of nifedipine. Filters were washed with $10 \mathrm{ml}$ of $20 \mathrm{mM}$ Tris $\cdot \mathrm{HCl}$ $(\mathrm{pH}$ 6.5) at room temperature and counted in a beta scintillation counter for $1 \mathrm{~min}$. The data were computer modeled using the Ligand program (8). At $0.1 \mathrm{nM}$ PN200-110, nonspecific binding was less than $30 \%$ of the total binding.

Drugs and Chemicals. The salts used in the pipette and bathing solutions were obtained from Sigma. The cAMP- dependent protein kinase inhibitor (PKI 5-24 Amide; Peninsula Laboratories) was used at a final concentration of $5.6 \mu \mathrm{M}$.

$\mathrm{G}_{\mathrm{s} \alpha}$ activated with the nonhydrolyzable GTP analog, GTP $\gamma$ S, was a kind gift from Jim Tomlinson at COR Therapeutics and used at a final concentration of $180 \mathrm{nM}$. Recombinant $\mathrm{G}_{\mathrm{s} \alpha}$ was purified from Escherichia coli (kindly supplied by A. Gilman, University of Texas Southwestern Medical Center, Dallas, TX) as described previously (9). $\mathrm{G}_{\mathrm{s} \alpha}$ was activated by incubation for $30 \mathrm{~min}$ at $30^{\circ} \mathrm{C}$ with $400 \mu \mathrm{M} \mathrm{GTP} \gamma \mathrm{S}$ in a solution consisting of: $10 \mathrm{mM} \mathrm{MgSO}_{4}, 50 \mathrm{mM}$ Hepes, 1.5 $\mathrm{mM}$ EDTA, and $11 \mathrm{mM}$ DTT (pH 8.0). Following the incubation, free GTP $\gamma \mathrm{S}$ was removed by gel filtration. $\mathrm{G}_{\mathrm{s} \alpha}-\mathrm{GTP} \gamma \mathrm{S}$ induced maximum stimulation of recombinant human type $\mathrm{V}$ adenylyl cyclase in HEK293 membranes at $100 \mathrm{nM}$.

Where indicated, intracellular cAMP stimulation was achieved by addition of a mixture containing 8-Br-cAMP (500 $\mu \mathrm{M}$; Sigma), isobutyl-methyl-xanthine (200 $\mu \mathrm{M}$; Sigma), and forskolin (10 $\mu \mathrm{M}$; Sigma).

Calculations and Statistical Analysis. Statistical significance was obtained by unpaired $t$-test comparison of sample groups of similar size (10). Average data values were expressed as the means \pm SEM. Statistical significance was accepted as $P<0.05$.

\section{RESULTS}

$I_{C a}$ of $\mathbf{G}_{\mathrm{s} \alpha}$ Transgenic Neonatal Cardiac Myocytes. Basal whole-cell $\mathrm{Ca}^{2+}$ currents were obtained (1-2 min after obtaining the patch) from either wild-type, nontransgenic littermates, or $\mathrm{G}_{\mathrm{s} \alpha}$-overexpressing transgenic mice (Fig. 1). The peak $\mathrm{I}_{\mathrm{Ca}}$ was $-155 \pm 24 \mathrm{pA} /$ cell $(n=19$, Fig. 2$)$ for the wild-type controls, thus similar to the control littermates
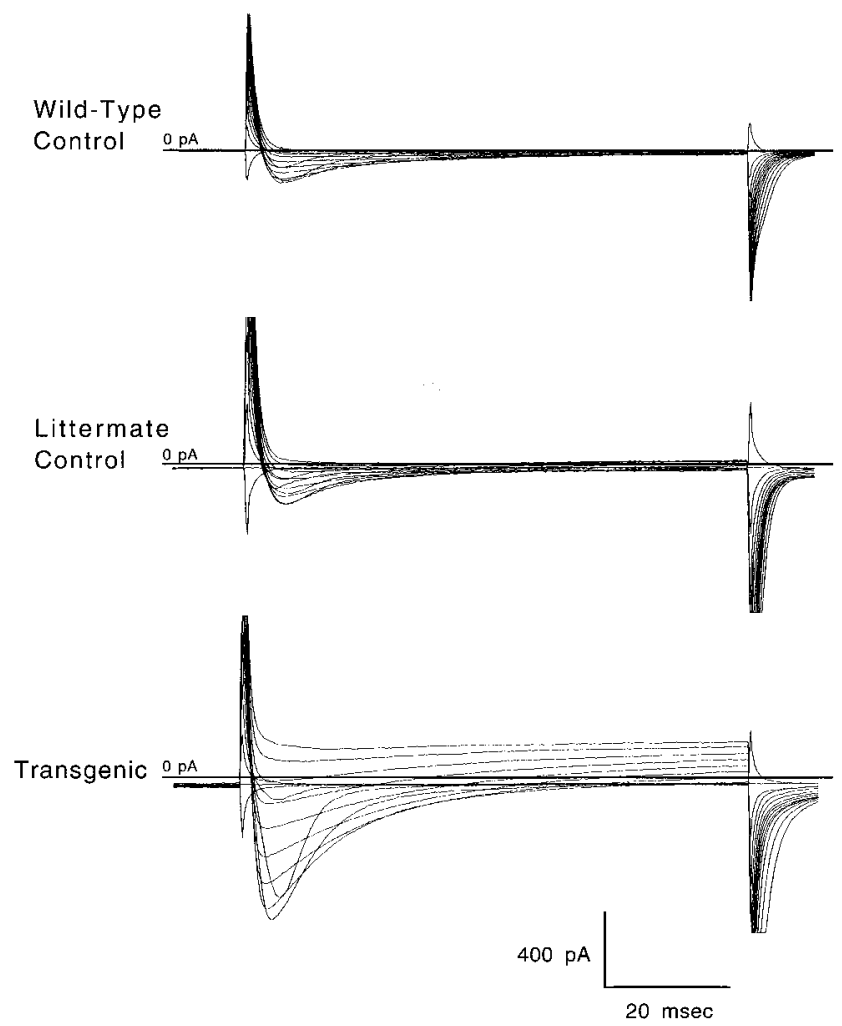

FIG. 1. Representative tracings of $\mathrm{Ca}^{2+}$ currents. Whole-cell $\mathrm{I}_{\mathrm{Ca}}$ were obtained from three groups of myocytes, wild-type controls (top tracings), nonexpressing littermates (middle tracings), and $\mathrm{G}_{\mathrm{s}^{-}}$ overexpressing transgenics (bottom tracings). $\mathrm{I}_{\mathrm{Ca}}$ were obtained from a holding potential of $-50 \mathrm{mV}$ to voltages between -60 and $70 \mathrm{mV}$. Line indicates 0 current level. Data are representative of 18-21 experiments. 


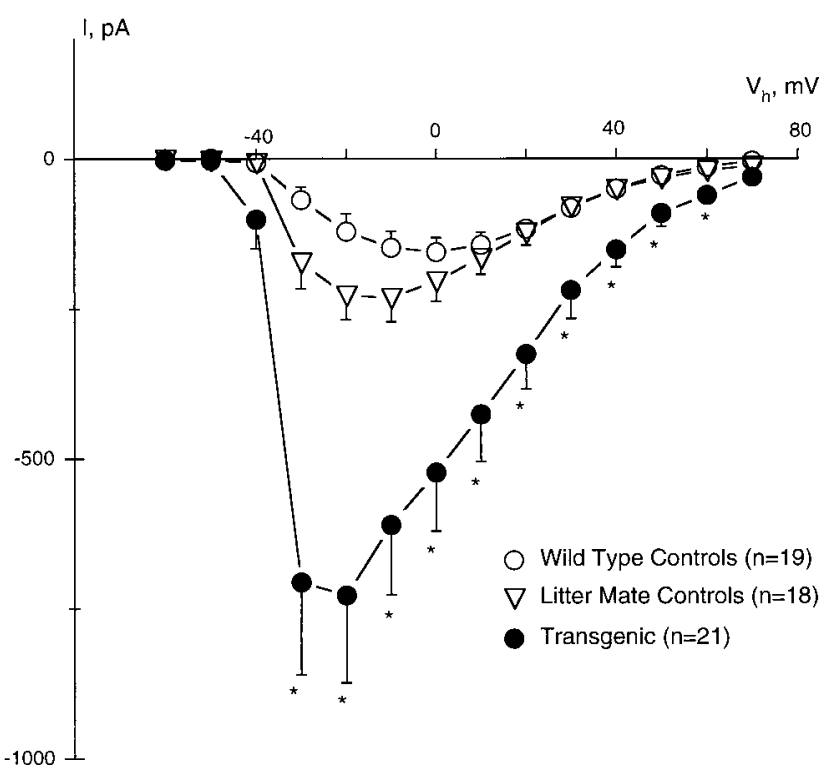

FIG. 2. Current-voltage relationships of $\mathrm{Ca}^{2+}$ currents. No statistical differences in the peak $\mathrm{Ca}^{2+}$ current-voltage relationships were detected between the wild-type controls and the control littermates. However, transgenic myocytes displayed a 5-fold increase in L-type $\mathrm{Ca}^{2+}$ currents compared with wild-type controls. $*, P<0.05$ between transgenics and wild-type controls.

$(-231 \pm 40 \mathrm{pA} /$ cell, $n=18, P<0.15)$. In contrast, $\mathrm{G}_{\mathrm{s} \alpha}$ transgenic neonatal cardiac myocytes displayed a 5-fold $(490 \%)$ enhancement in the $\mathrm{I}_{\mathrm{Ca}}(-727 \pm 146 \mathrm{pA} /$ cell, $n=21$, $P<0.001)$ compared with either wild-type or control littermates. The peak of the $I-V$ relationship shifted from a median step potential of $0 \mathrm{mV}$ to $-10 \mathrm{mV}$ and $-30 \mathrm{mV}$ for littermate controls and transgenic myocytes, respectively (Fig. 2), thus suggesting a change in the voltage dependence of activation by $\mathrm{G}_{\mathrm{s} \alpha}$. This is unlikely due to a space-clamping artifact as the round shape and size of the various cardiac myocytes was the same. Nevertheless, a comparison of $\mathrm{I}_{\mathrm{Ca}}$ at step potentials between 0 and $60 \mathrm{mV}$, where there is no loss of voltage control, indicated that the currents recorded in the transgenic myocytes were significantly greater than those of either the control littermates or the wild-type myocytes $(P<0.01$ for all cases).

The possibility that contaminating $\mathrm{Na}^{+}$currents influenced the magnitude of the $\mathrm{I}_{\mathrm{Ca}}$ in the transgenic mice was also investigated. The peak $\mathrm{I}_{\mathrm{Na}}$ for the $\mathrm{G}_{\mathrm{s} \alpha}$ transgenic myocytes was $4.7 \pm 1.0 \mathrm{nA} /$ cell $(n=3)$, thus similar to the control littermates $(3.9 \pm 0.7 \mathrm{nA} /$ cell, $n=7, P<0.7)$ and the wild-type myocytes (4.1 $\pm 1.3 \mathrm{nA} /$ cell, $n=5, P<0.8)$. Therefore, the observed differences were not a result of changes in $\mathrm{Na}^{+}$conductance.

L-Type Calcium Channel Expression of $\mathbf{G}_{\mathrm{s} \alpha}$ Transgenic Cardiac Myocytes. To test the possibility that the increase in $\mathrm{I}_{\mathrm{Ca}}$ in the transgenic mice was due to an increase in L-type $\mathrm{Ca}^{2+}$ channel number, affinity-binding studies with $\left[{ }^{3} \mathrm{H}\right] \mathrm{PN} 200-110$ were performed on both $\mathrm{G}_{\mathrm{s} \alpha}$ transgenic and wild-type control mice. The binding affinity, $K_{\mathrm{d}}$, was $0.107 \pm 0.012 \mathrm{nM}(n=8)$ for the control mice and $0.124 \pm 0.014 \mathrm{nM}(n=8)$ for the transgenic mice $(P<0.39)$. Likewise, the maximum binding capacity, $\mathrm{B}_{\max }$, was similar between the control and transgenic mice $(175 \pm 10 \mathrm{fmol} / \mathrm{mg}$ protein vs. $192 \pm 9 \mathrm{fmol} / \mathrm{mg}$ protein for the control and transgenic mice, respectively, $P<0.24$ ). Similar results were observed by Western blotting (data not shown).

$I_{\text {Ca }}$ of Control Neonatal Cardiac Myocytes Dialyzed with Activated $\mathbf{G}_{\mathbf{s} \boldsymbol{\alpha}}$. To further test the possibility that $\mathrm{G}_{\mathrm{s} \alpha}$ itself, and not an adaptive mechanism associated with overexpression of the protein was the cause of $I_{C a}$ enhancement in the $G_{s \alpha}$ transgenic mice, wild-type cardiac myocytes were dialyzed with
GTP $\gamma$ S-activated $G_{\mathrm{s} \alpha}$ to mimic the effect of $\mathrm{G}_{\mathrm{s} \alpha}$ overexpression. Intracellular dialysis with activated $\mathrm{G}_{\mathrm{s} \alpha}(180 \mathrm{nM})$ induced a $210 \%$ increase in the peak $\mathrm{I}_{\mathrm{Ca}}$, ranging from -234 to -1052 $\mathrm{pA}(n=6)$. Thus, the peak $\mathrm{I}_{\mathrm{Ca}}$ was statistically higher than that of wild-type controls $(-482 \pm 160 \mathrm{pA} /$ cell, $n=6, P<0.05$, Fig. 3 ) and statistically indistinguishable from the values obtained with the $\mathrm{G}_{\mathrm{s} \alpha}$-overexpressing transgenic myocytes $(P<0.20)$.

Nevertheless, the onset of voltage activation and the voltage response, which was faster than in the wild-type myocytes, also suggested the possibility that the $\mathrm{Ca}^{2+}$ entry step may also activate a mechanism for the regulation of other ion conductances. Therefore, the possibility that $\mathrm{Ca}^{2+}$-dependent $\mathrm{Cl}^{-}$ currents (11) may contribute to the magnitude and kinetics of the currents measured was examined by increasing the $\mathrm{Ca}^{2+}$ buffering capacity of the internal (pipette) solution with 10 $\mathrm{mM}$ 1,2-bis(2-aminophenoxy)ethane- $N, N, N^{\prime}, N^{\prime}$-tetraacetic acid. In the presence of $10 \mathrm{mM}$ 1,2-bis(2-aminophenoxy)ethane- $N, N, N^{\prime}, N^{\prime}$-tetraacetic acid and $180 \mathrm{nM}$ GTP $\gamma \mathrm{S}$ activated $\mathrm{G}_{\mathrm{s} \alpha}$, the peak $\mathrm{I}_{\mathrm{Ca}}$ was $-582 \pm 178 \mathrm{pA} /$ cell $(n=8, P<$ 0.7 , Fig. 3), thus similar to the myocytes dialyzed with GTP $\gamma \mathrm{S}$ activated $\mathrm{G}_{\mathrm{s} \alpha}$ and the standard pipette solution containing 5 mM EGTA $(P<0.5)$. Thus, decreasing the free cytosolic $\mathrm{Ca}^{2+}$ did not affect the $\mathrm{I}_{\mathrm{Ca}}$ induced by dialysis with GTP $\gamma \mathrm{S}$-activated $\mathrm{G}_{\mathrm{s} \alpha}$. Similar results were also obtained with $15 \mathrm{mM}$ EGTA (data not shown).

Effect of PKA Inhibition on the $\mathbf{G}_{\mathbf{s} \alpha}$-Mediated Increase in $\mathbf{I}_{\mathbf{C a}}$. To further examine whether $\mathrm{G}_{\mathrm{s} \alpha}$ enhancement of $\mathrm{I}_{\mathrm{Ca}}$ was independent of $\mathrm{G}_{\mathrm{s} \alpha}$ activation of the cAMP pathway, both wild-type and $\mathrm{G}_{\mathrm{s} \alpha}$-overexpressing myocytes were dialyzed with the PKA inhibitor, PKI $(5.6 \mu \mathrm{M})$, in the presence or absence of $\mathrm{G}_{\mathrm{s} \alpha}-\mathrm{GTP} \gamma \mathrm{S}(180 \mathrm{nM})$, respectively. The peak $\mathrm{I}_{\mathrm{Ca}}$ of $\mathrm{G}_{\mathrm{s} \alpha}-$ GTP $\gamma$ S-activated wild-type myocytes in the presence of PKI was $-623 \pm 146 \mathrm{pA} /$ cell $(n=9, P<0.01$ compared with control wild-type currents, Fig. 4), thus similar to the values observed under control conditions in the $\mathrm{G}_{\mathrm{s} \alpha}$-overexpressing transgenic myocytes $(P<0.30)$. Furthermore, intracellular dialysis with PKI $(5.6 \mu \mathrm{M})$ was without effect on the enhanced

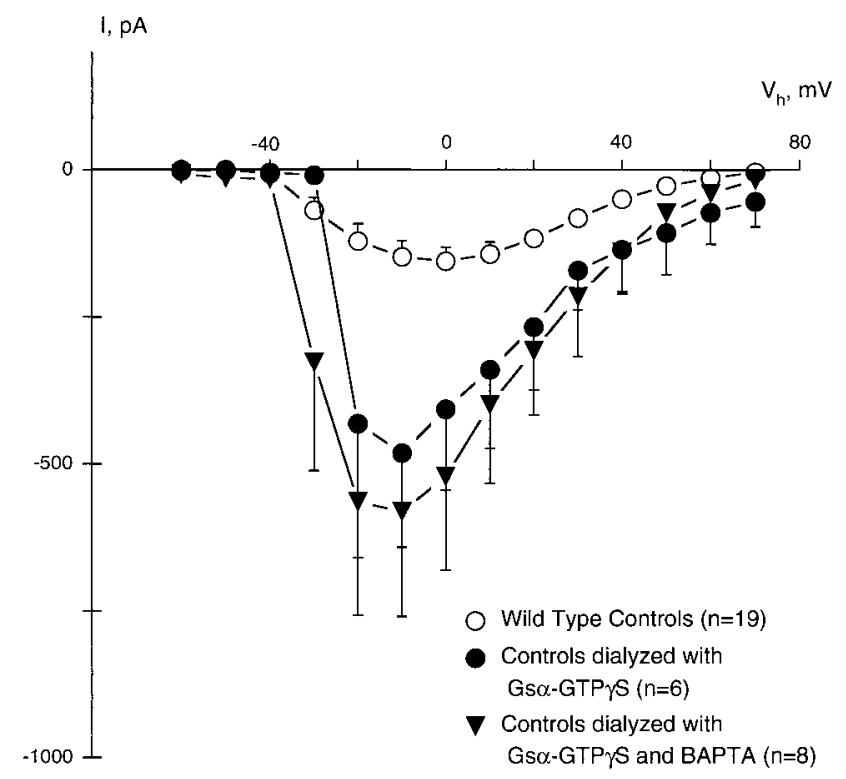

FIG. 3. Current-voltage relationships of wild-type cardiac myocytes dialyzed with activated $\mathrm{G}_{\mathrm{s} \alpha}$. Dialysis of wild-type controls with $\mathrm{GTP} \gamma \mathrm{S}$-activated $\mathrm{G}_{\mathrm{s} \alpha}(180 \mathrm{nM})$ significantly increased the peak of the current-voltage relationship compared with controls. No statistical differences were detected between the dialyzed controls and $\mathrm{G}_{\mathrm{s} \alpha^{-}}$ overexpressing transgenic myocytes. Increasing the $\mathrm{Ca}^{2+}$ buffering capacity of the pipette solution did not significantly affect the peak of the current-voltage relationship in the GTP $\gamma \mathrm{S}$-activated $\mathrm{G}_{\mathrm{s} \alpha}$-dialyzed myocytes. 


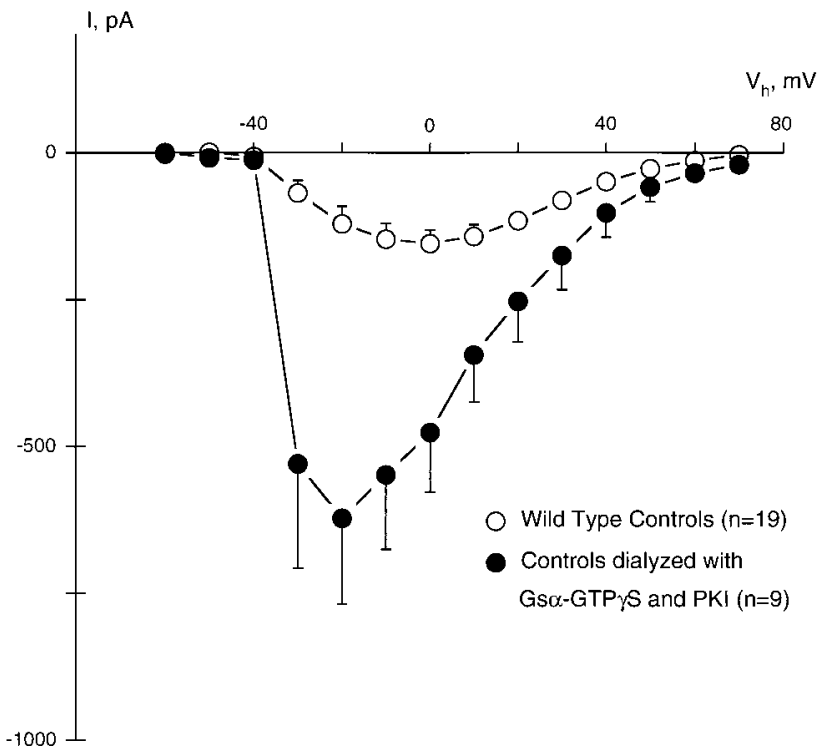

FIG. 4. Effect of PKA inhibition on the current-voltage relationships of wild-type controls. Wild-type myocytes were dialyzed with GTP $\gamma$ S-activated $\mathrm{G}_{\mathrm{s} \alpha}(180 \mathrm{nM})$ and a PKA inhibitor (PKI, 5.6 $\left.\mu \mathrm{M}\right)$. The presence of PKI did not prevent the increase in the peak of the current-voltage relationship observed with $\mathrm{G}_{\mathrm{s} \alpha}$ alone.

$I_{\mathrm{Ca}}$ of $\mathrm{G}_{\mathrm{s} \alpha}$ transgenic myocytes (Fig. 5), since the peak $\mathrm{I}_{\mathrm{Ca}}$ of the PKI-dialyzed $\mathrm{G}_{\mathrm{s} \alpha}$ transgenic myocytes was identical to the nondialyzed transgenic myocytes $(-568 \pm 117 \mathrm{pA} /$ cell vs. $-727 \pm 146 \mathrm{pA} /$ cell, $n=3, P<0.25$, Fig. 5).

The inhibitory effect of PKI on PKA activation elicited by a cAMP stimulatory mixture was independently verified on cAMP-activated $\mathrm{Cl}^{-}$currents (Table 1 ) recently reported in this cell model (7). cAMP stimulation in symmetrical $\mathrm{Cl}^{-}$ elicited a $1636 \%$ increase in $\mathrm{Cl}^{-}$conductance, which was completely blocked by intracellular dialysis with 5.6 $\mu \mathrm{M}$ PKI.

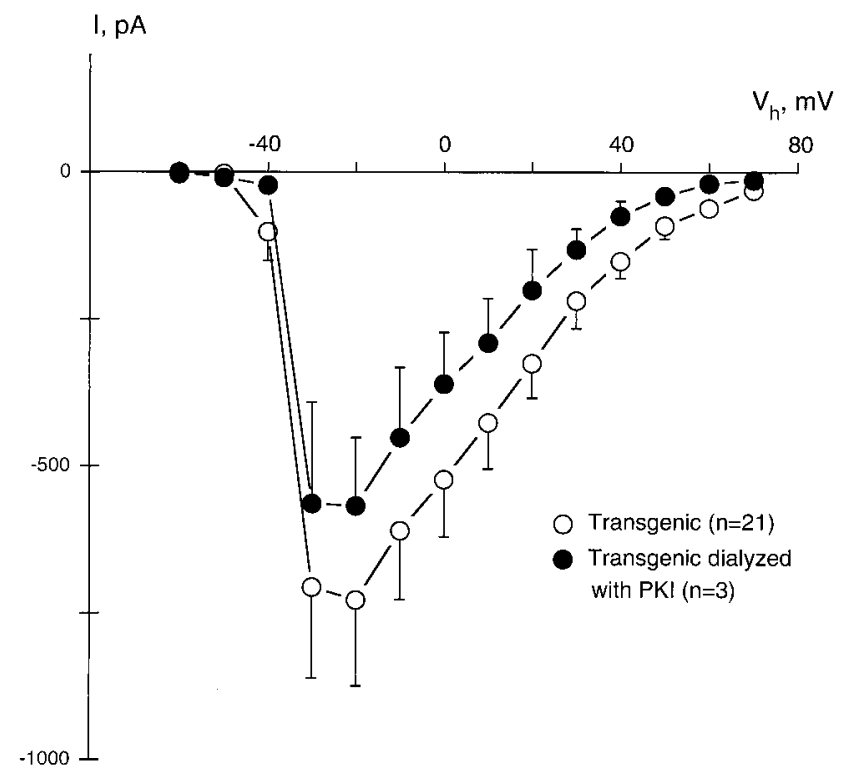

FIG. 5. Effect of PKA inhibition on the current-voltage relationships of $\mathrm{G}_{\mathrm{s} \alpha}$ transgenic myocytes. Myocytes from the $\mathrm{G}_{\mathrm{s} \alpha}$ transgenic group were dialyzed with a PKA inhibitor $(\mathrm{PKI}, 5.6 \mu \mathrm{M})$. The presence of PKI did not decrease the peak of the current-voltage relationship observed in the nondialyzed myocytes. Peak $\mathrm{Ca}^{2+}$ currents were statistically similar to the basal values observed in the transgenic myocytes and in the wild-type myocytes dialyzed with GTP $\gamma \mathrm{S}$ activated $\mathrm{G}_{\mathrm{s} \alpha}$ and PKI.
Table 1. PKI inhibition of cAMP-stimulated whole-cell $\mathrm{Cl}$ conductance

\begin{tabular}{lcc}
\hline & Basal, nS/cell & $\begin{array}{c}\text { cAMP-stimulated, } \\
\text { nS/cell }\end{array}$ \\
\hline Control $(n=6)$ & $0.33 \pm 0.12$ & $5.73 \pm 1.32^{*}$ \\
+ PKI $(n=3)$ & $0.48 \pm 0.20$ & $0.59 \pm 0.35^{\dagger}$ \\
\hline
\end{tabular}

Whole-cell $\mathrm{Cl}^{-}$currents were measured as described in Materials and Methods under symmetrical $\mathrm{Cl}^{-}$conditions. The pipette and bath solutions were as described for $\mathrm{I}_{\mathrm{Ca}}$ measurements. Addition of the cAMP stimulatory mixture resulted in an increase in highly linear and time-independent whole-cell currents in the control myocytes, but was without effect on the myocytes dialyzed with PKI. These cAMPstimulated $\mathrm{Cl}^{-}$currents have been recently characterized (7). ${ }^{*} P<0.05$ compared with controls.

$\dagger P<0.05$ compared with cAMP-stimulated control myocytes.

Thus indicating that PKI is indeed effective in blocking PKA-dependent phosphorylation.

Kinetic Comparison of $\mathbf{G}_{\mathrm{s} \alpha}-\mathbf{G T P} \gamma \mathbf{S}$ Activation of Control and Transgenic Neonatal Cardiac Myocytes. To further assess whether any kinetic differences in $\mathrm{G}_{\mathrm{s} \alpha}$ activation of the control and transgenic neonatal myocytes existed, the onset of activation and, subsequently, rundown of the $\mathrm{I}_{\mathrm{Ca}}$ were followed for the control, $\mathrm{G}_{\mathrm{s} \alpha}$-overexpressing, and GTP $\gamma \mathrm{S}$-activated $\mathrm{G}_{\mathrm{s} \alpha^{-}}$ dialyzed control myocytes (Fig. 6). Activation of $\mathrm{I}_{\mathrm{Ca}}$ by intracellular dialysis with $\mathrm{G}_{\mathrm{s} \alpha}-\mathrm{GTP} \gamma \mathrm{S}$ occurred as early as the first experimental data collection was achieved. Onset of activation was identical to that obtained in the transgenic myocytes, consistent with the expected intracellular dialysis of activated $\mathrm{G}_{\mathrm{s} \alpha}$. Furthermore, $\mathrm{I}_{\mathrm{Ca}}$ rundown was similar in both the activated control myocytes and transgenic myocytes. Thus, cells dialyzed with $\mathrm{G}_{\mathrm{s} \alpha}-\mathrm{GTP} \gamma \mathrm{S}$ for approximately $4 \mathrm{~min}$ still had peak currents significantly larger than the nondialyzed wildtype myocytes $(-275 \pm 49 \mathrm{pA} /$ cell vs. $-129 \pm 34 \mathrm{pA} /$ cell, $P<$ 0.05 , Fig. 6), yet were similar to the $G_{\mathrm{s} \alpha}$ transgenic myocytes

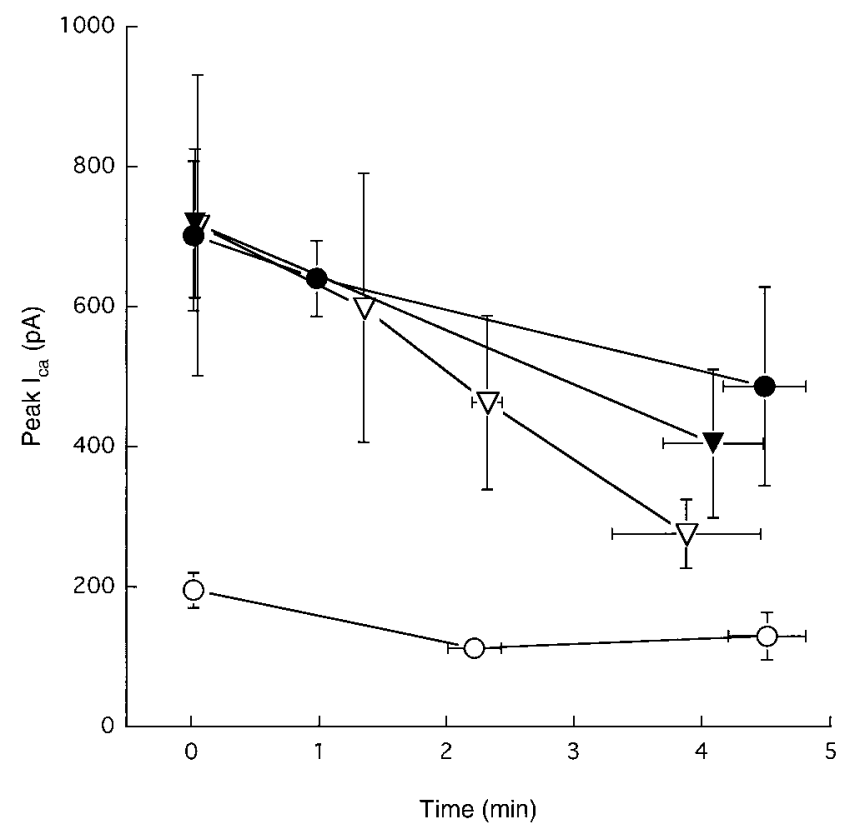

FIG. 6. Time-dependent $\mathrm{I}_{\mathrm{Ca}}$ activation and rundown in wild-type and $\mathrm{G}_{\mathrm{s} \alpha}$ transgenic neonatal cardiac myocytes. The absolute value of the peak of the calcium current was followed for several minutes in wild-type myocytes under basal conditions (open circles, $n=4$ ), $\mathrm{G}_{\mathrm{s} \alpha}$-overexpressing transgenic myocytes (filled circles, $n=5$ ), wildtype myocytes dialyzed with GTP $\gamma$ S-activated $\mathrm{G}_{\mathrm{s} \alpha}(180 \mathrm{nM}$, open triangles, $n=5$ ), and wild-type myocytes dialyzed with GTP $\gamma \mathrm{S}$ activated $\mathrm{G}_{\mathrm{s} \alpha}(180 \mathrm{nM})$ and PKI $(5.6 \mu \mathrm{M}$, filled triangles, $n=5)$. The first measurements were typically taken about $10 \mathrm{~s}$ after obtaining the whole-cell patch. 
$(-275 \pm 49 \mathrm{pA} /$ cell vs. $-486 \pm 142 \mathrm{pA} /$ cell, $P<0.15$, Fig. 6$)$ Similar kinetics of activation and rundown were also observed in control cells dialyzed with $\mathrm{G}_{\mathrm{s} \alpha}-\mathrm{GTP} \gamma \mathrm{S}$ and PKI, which, after $4 \mathrm{~min}$, had significantly larger $\mathrm{I}_{\mathrm{Ca}}$ compared with wild-type cells $(-404 \pm 106 \mathrm{pA} /$ cell vs. $-129 \pm 34 \mathrm{pA} /$ cell, $P<0.05$, Fig. $6)$, yet were similar to both the wild-type cells dialyzed with $\mathrm{G}_{\mathrm{s} \alpha}-\mathrm{GTP} \gamma \mathrm{S}$ alone $(P<0.50)$ and the $\mathrm{G}_{\mathrm{s} \alpha}$-overexpressing myocytes $(P<0.50)$. These data are most consistent with an effect solely elicited by uncomplexed $\mathrm{G}_{\mathrm{s} \alpha}\left(\mathrm{G}_{\mathrm{s} \alpha}\right.$ uncoupled from $\mathrm{G}_{\beta \gamma}$ ) on $\mathrm{I}_{\mathrm{Ca}}$ in $\mathrm{G}_{\mathrm{s} \alpha}$ transgenic myocytes and the $\mathrm{G}_{\mathrm{s} \alpha}-\mathrm{GTP} \gamma \mathrm{S}$ dialyzed wild-type cells.

\section{DISCUSSION}

The molecular details of ion channel regulation by $\mathrm{G}$ proteins are still a subject of interest and current controversy (for a compelling review, see ref. 12). Both activation of second messenger systems as well as a more direct interaction among the various $G$ proteins and ion channels have been postulated (12). Indeed, direct regulation of $\mathrm{Ca}^{2+}$ channels by $\mathrm{G}_{\mathrm{s}}$ has been strongly suggested by previous studies $(13,14)$. However, based on both the onset of $\mathrm{I}_{\mathrm{Ca}}$ stimulation by isoproterenol and complete inhibition by cAMP antagonists and PKA inhibitors, a tight $\beta$-AR second messenger pathway seems required for $\mathrm{Ca}^{2+}$ channel regulation in various cardiac preparations (3). Specific species and developmental differences may also play a role in what seems to be different pathways implicated in L-type $\mathrm{Ca}^{2+}$ channel regulation. Nevertheless, various regulatory pathways of a single target-effector system may not necessarily be mutually exclusive but will offer alternative mechanisms of activation and adaptation.

In the present study, we explored one particular aspect of this issue by determining the role of $\mathrm{G}_{\mathrm{s} \alpha}$ overexpression on the basal L-type $\mathrm{Ca}^{2+}$ channel activity of neonatal mouse cardiac myocytes. Cardiac myocytes obtained from three groups of mice were studied, including nonrelated wild-type mice and both nonexpressing and $\mathrm{G}_{\mathrm{s} \alpha}$-overexpressing transgenic littermates. The results in this report indicate that transgenic $G_{s \alpha}$ overexpression resulted in a constitutive enhancement of $\mathrm{I}_{\mathrm{Ca}}$ in neonatal mouse cardiac myocytes. Furthermore, $\mathrm{G}_{\mathrm{s} \alpha}$ transgenic myocytes dialyzed with the PKI had similar enhanced $\mathrm{I}_{\mathrm{Ca}}$ compared with nondialyzed $\mathrm{G}_{\mathrm{s} \alpha}$ transgenic myocytes, suggesting that an active PKA was not responsible for the increased $\mathrm{I}_{\mathrm{Ca}}$ of transgenic cardiac myocytes.

At least two possibilities exist to explain the enhanced $\mathrm{I}_{\mathrm{Ca}}$ in the transgenic animals. One possibility is that chronic $\mathrm{G}_{\mathrm{s} \alpha}$ overexpression may be associated with an adaptive increase in either channel number and/or up-regulation of regulatory subunits including $\beta \gamma$ complexes, also required for maintaining a proper $G$ protein signaling pathway. Thus, to test the hypothesis that $\mathrm{G}_{\mathrm{s} \alpha}$ did not require any other "regulatory" mechanisms for enhancing $\mathrm{I}_{\mathrm{Ca}}$ nor was it associated with the up-regulated expression of L-type $\mathrm{Ca}^{2+}$ channels, wild-type myocytes were dialyzed with GTP $\gamma \mathrm{S}$-activated $\mathrm{G}_{\mathrm{s} \alpha}$. This maneuver elicited a response similar to that observed in the $G_{s}$ transgenic mice. Thus, acute exposure to uncomplexed $\mathrm{G}_{\mathrm{s} \alpha}$ was sufficient to elicit an increase in $\mathrm{I}_{\mathrm{Ca}}$ identical to that observed by targeted gene overexpression, implying that this effect is not associated with adaptive changes in expression of the L-type $\mathrm{Ca}^{2+}$ channel or other regulatory proteins. This is further supported by the fact that channel expression, as determined by dihydropyridine binding, was identical in the control and $\mathrm{G}_{\mathrm{s} \alpha}$ transgenic myocytes.

Another possibility worth considering is a tonic stimulation of the cAMP pathway, including a consequent higher basal PKA activity, and thus $\mathrm{Ca}^{2+}$ channel phosphorylation in the $\mathrm{G}_{\mathrm{s} \alpha}$-overexpressing cardiac myocytes. The lack of an effect of PKI in the transgenic animals may not necessarily affect $\mathrm{Ca}^{2+}$ channels which are already phosphorylated, for example, nor does it rule out the converse possibility, namely, that $\mathrm{G}_{\mathrm{s} \alpha}$ overexpression may be somehow linked to a decrease in phosphatase activity, which would then enhance basal ion channel phosphorylation. To assess this possibility, acute intracellular dialysis of wild-type cardiac myocytes with activated $\mathrm{G}_{\mathrm{s} \alpha}$ was also conducted in the presence of PKI. This maneuver would be expected to preclude any "chronic" regulatory effect associated with either an increased ion channel phosphorylation or channel number, as the cells would be dialyzed in a basal state, preventing both the onset of ion channel phosphorylation and up-regulation of functional channels. Intracellular dialysis of wild-type cardiac myocytes with both activated $\mathrm{G}_{\mathrm{s} \alpha}$ and PKI elicited an effect identical to that observed in the transgenic myocytes.

Although our data cannot at present rule out regulatory mechanisms, implying a role of $\mathrm{G}_{\mathrm{s} \alpha}$ on intracellular phosphatases, for example, this possibility is highly unlikely because the expected level of prior phosphorylation invoked under either condition, namely, acute addition or transgenic expression of $\mathrm{G}_{\mathrm{s} \alpha}$, would have to be identical for both signals to be of similar magnitude. However, our results are in agreement with previous findings on both excised cardiac membrane patches (2) and reconstituted $\mathrm{Ca}^{2+}$ channels in lipid bilayer systems (2, 13 ), indicating that addition of activated $\mathrm{G}_{\mathrm{s} \alpha}$ can indeed increase $\mathrm{I}_{\mathrm{Ca}}$ and prolong $\mathrm{Ca}^{2+}$ channel activity in the apparent absence of a functional cAMP pathway, including PKA. Although this evidence is compelling, these experiments were largely performed after $\beta$-AR activation of the myocytes with isoproterenol, thus an interaction between the adenylyl cyclase complex, including $\mathrm{G}_{\mathrm{s}}$ and the L-type $\mathrm{Ca}^{2+}$ channels, could not be ruled out.

Our results are also in agreement with the previous findings reported by Pelzer et al. (15) using guinea pig cardiac myocytes. In those studies, PKA was inhibited with phosphorylation pathway inhibitory agents. With the phosphorylation pathway blocked, this group reported that isoproterenol was able to increase $\mathrm{I}_{\mathrm{Ca}}$ by $55 \%$, yet forskolin decreased $\mathrm{I}_{\mathrm{Ca}}$ by $15 \%$. Intracellular dialysis with either GTP $\gamma \mathrm{S}$ or preactivated $\mathrm{G}_{\mathrm{s}}$ also increased $\mathrm{I}_{\mathrm{Ca}}$ by about $50 \%$ (15). Although these results confirm the existence of a membrane-delimited pathway for $\beta$-AR stimulation of L-type $\mathrm{Ca}^{2+}$ channels, our results demonstrate that the presence of $\mathrm{G}_{\mathrm{s} \alpha}$ will increase $\mathrm{I}_{\mathrm{Ca}}$ in the absence of $\beta$-AR stimulation.

An adenylyl cyclase independent pathway of $\mathrm{G}_{\mathrm{s} \alpha}$ regulation of the L-type $\mathrm{Ca}^{2+}$ channel remains controversial. Intracellular dialysis with PKI, for example, completely blocked the isoproterenol-stimulated increase in $\mathrm{I}_{\mathrm{Ca}}$ in frog and guinea pig adult cardiac myocytes, thus suggesting that $\beta$-AR stimulation of $\mathrm{I}_{\mathrm{Ca}}$ was solely dependent on PKA activation (3). However, the present data on neonatal mouse cardiac myocytes indicated that neither $\beta$-AR stimulation nor an active PKA is required for the regulation by $\mathrm{G}_{\mathrm{s} \alpha}$ of $\mathrm{L}$-type $\mathrm{Ca}^{2+}$ channels. These results argue that the increase in $\mathrm{I}_{\mathrm{Ca}}$ observed in the present study resulted solely from the presence of an active $G_{\mathrm{s} \alpha}$ and not PKA. This difference with other cell models, however, may imply either species and/or developmental differences which will require future experimentation.

The data presented here suggest that $\mathrm{G}_{\mathrm{s} \alpha}$ may be responsible for maintaining a baseline for cardiac myocyte function and providing amplification of the $\beta$-AR signaling pathway. This hypothesis is largely dependent on the ability of $\mathrm{G}_{\mathrm{s} \alpha}$ to regulate effector molecules independent of adenylyl cyclase and PKA. Although these results do not necessarily imply a direct interaction between $\mathrm{G}_{\mathrm{s} \alpha}$ and the L-type $\mathrm{Ca}^{2+}$ channel, this is the simplest and most feasible explanation, which is also supported by previous findings where direct binding between $\mathrm{G}_{\mathrm{s} \alpha}$ and the L-type $\mathrm{Ca}^{2+}$ channel has already been demonstrated (14).

The present study demonstrates that $\mathrm{G}_{\mathrm{s} \alpha}$ overexpression results in a constitutive enhancement in L-type $\mathrm{Ca}^{2+}$ currents in neonatal mouse cardiac myocytes. This stimulation does not 
require an active PKA, and thus is likely independent of the cAMP pathway elicited by $\beta$-AR stimulation.

We gratefully acknowledge Drs. Richard L. Sidman and Aizhong Li (Department of Neurology, New England Regional Primate Research Center, Harvard Medical School) for the kind gift of pregnant mice (C57BL/6J +/+, P100) and Mr. George R. Jackson, Jr. for excellent technical assistance in the preparation of primary cultures of mouse cardiac myocytes. We also thank Dr. David Clapham for his helpfu comments. This work was supported by a grant-in-Aid from the American Heart Association (to H.F.C.) and with funds contributed in part by the American Heart Association, Massachusetts Affiliate (to H.F.C.), and by U.S. Public Health Service Grants HL 38070, HL 37404, and HL 45332 (to D.E.V. and S.F.V.).

1. Trautwein, W. \& Hescheler, J. (1990) Annu. Rev. Physiol. 52, 257-274

2. Yatani, A., Codina, J., Imoto, Y., Reeves, J. P., Birnbaumer, L. \& Brown, A. M. (1987) Science 238, 1288-1292.

3. Hartzell, H. C., Mery, P. F., Fischmeister, R. \& Szabo, G. (1991) Nature (London) 351, 573-576.

4. Gaudin, C., Ishikawa, Y., Wright, D. C., Mahdavi, V., NadalGinard, B., Wagner, T. E., Vatner, D. E. \& Homcy, C. J. (1995)
J. Clin. Invest. 95, 1676-1683.

5. Hogan, B., Beddington, R., Costantini, F. \& Lacy, E. (1994) Manipulating the Mouse Embryo. A Laboratory Manual (Cold Spring Harbor Lab. Press, Plainview, NY)

6. Kozlowski, R. Z., Goodstadt, L. J., Twist, V. W. \& Powell, T. (1992) Proc. R. Soc. London 250, 35-42.

7. Lader, A. S., Jackson, G. R. \& Cantiello, H. F. (1998) Biophys. J. 74, A343 (abstr.).

8. Munson, P. J. \& Rodbard, D. (1980) Anal. Biochem. 107, 220-239.

9. Lee, E., Linder, M. E. \& Gilman, A. G. (1994) Methods Enzymol. 237, 146-164.

10. Snedecor, G. W. \& Cochran, W. G. (1973) Statistical Methods (Iowa State Univ. Press, Ames), pp. 104-106.

11. Zygmunt, A. C. \& Gibbons, W. R. (1991) Circ. Res. 68, 424-437.

12. Wickman, K. \& Clapham, D. E. (1995) Physiol. Rev. 75, 865-885.

13. Imoto, Y., Yatani, A., Reeves, J. P., Codina, J., Birnbaumer, L. \& Brown, A. M. (1988) Am. J. Physiol. 255, H722-H728.

14. Hamilton, S. L., Codina, J., Hawkes, M. J., Yatani, A., Sawada, T., et al. (1991) J. Biol. Chem. 266, 19528-19535.

15. Pelzer, S., Shuba, Y. M., Asai, T., Codina, J., Birnbaumer, L., McDonald, T. F. \& Pelzer, D. (1990) Am. J. Physiol. 259, H264-H267. 